\title{
Comment on "Streamflow input to Lake Athabasca, Canada" by Rasouli et al. (2013)
}

\section{L. Peters}

Environment Canada, Water \& Climate Impacts Research Centre, POB 3060 STN CSC, University of Victoria, Victoria, British Columbia, Canada

Correspondence to: D. L. Peters (daniel.peters@ec.gc.ca)

Received: 10 December 2013 - Published in Hydrol. Earth Syst. Sci. Discuss.: 20 March 2014

Revised: - - Accepted: 28 July 2014 - Published: 12 September 2014

\begin{abstract}
This comment paper addresses data and analysis issues in a paper entitled "Streamflow Input to Lake Athabasca, Canada" by Rasouli et al. (2013). Analyses of observed and naturalized lake level data for Lake Athabasca are redone in this comment paper with corrected hydrometric data to provide northerners and researchers with the correct information for environmental assessments. The comment paper also highlights the importance of including in the analysis not only direct inflows to Lake Athabasca, but also the hydraulic influences on lake outflow, especially when meaningful future projections of lake levels are required for water management.
\end{abstract}

\section{Comment}

Rasouli et al. (2013; henceforth referred to as RHD) investigated change points and monotonic trends in tributary inflow to and water level time series of Lake Athabasca in northwestern Canada (Fig. 1). RHD reported a significant $(p<0.05)$ reduction in overall annual total lake inflow and a probable $(p=0.10)$ recession in the mean annual Lake Athabasca level over the 1960-2010 study period, and suggested that the lake level may drop 2 to $3 \mathrm{~m}$ by the year 2100 given the current decline, threatening the flora and fauna of the lake and negatively impacting the ecological cycle of the adjacent Peace-Athabasca Delta (PAD; Ramsar Convention wetland of international importance). RHD further stated that the main objective of their study was to assess contemporary changes to Lake Athabasca hydrology and contextualize these results with millennium-scale paleo-lake level reconstruction derived from sediment cores studies. They refer to the work of Wolfe et al. (2011), who reported 2 to $4 \mathrm{~m}$ lower lake levels during the mid-Holocene (5200 to $2500 \mathrm{yr} \mathrm{BP}$ ) compared to the 20th century mean of $209 \mathrm{~m}$ a.s.l. (above sea level), a magnitude similar to RHD's extrapolated decline by the end of the 21 st century.

Not reported in RHD was that Wolfe et al. (2011) also inferred $\mathrm{a} \sim 2 \mathrm{~m}$ higher lake level during the Little Ice Age period (AD 1600-1900), which is in the range of the historical extreme peak daily levels observed during the summers of 1935 and 1936 at the west end of the lake at the Fort Chipewyan hydrometric gauge (07MD001; Environment Canada, 2013). The lake system has thus experienced a considerable range of water levels since proglacial Lake McConnell separated ( $~ 8300 \mathrm{yr}$ BP) into three great lakes (Great Bear, Great Slave and Lake Athabasca) and sedimentation by the Athabasca, Peace and Birch rivers developed deltas at the west end of Lake Athabasca, coalescing to form large, shallow internal lakes that today cover almost onethird of the total areal extent of the present-day deltaic complex $\left(\sim 6000 \mathrm{~km}^{2}\right)$ (PAD-PG, 1973) (Fig. 1). As will be outlined below, when investigating the PAD-Lake Athabasca system, it is important to consider not only changes in water available for storage in the lake, as done by RHD and inferred by Wolfe et al. (2011), but also climatic, geomorphic and anthropogenic-driven changes to hydraulic controls that have influenced lake levels when interpreting paleoreconstructions and understating contemporary conditions (see Peters et al., 2006). For instance, it will be shown that meaningful projections of future lake levels must include key physical processes that control lake outflow, such as the influence of the Peace River. 


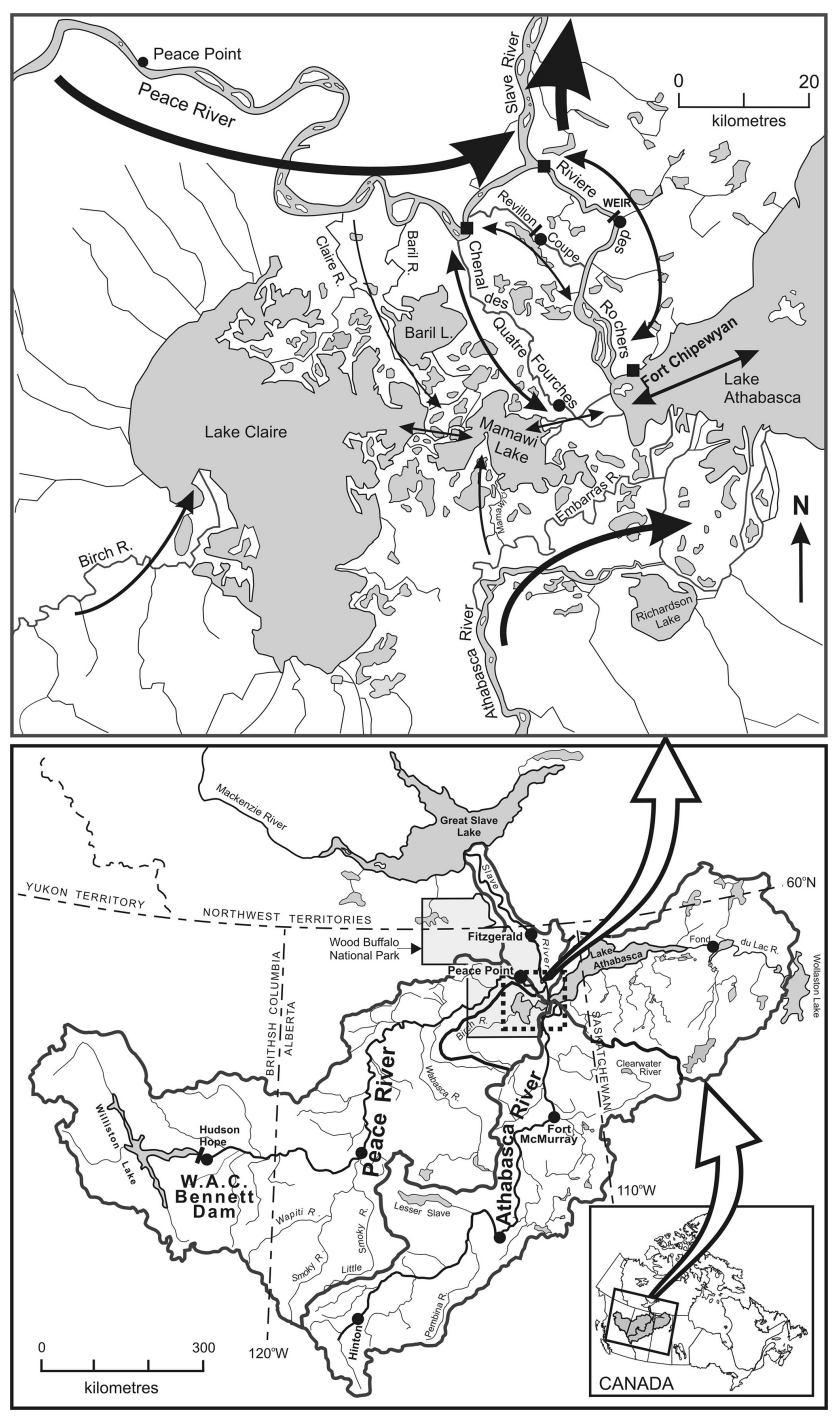

Figure 1. Major drainage basins of the Lake Athabasca-Peace Athabasca Delta system, along with a large-scale map of the delta with black arrows indicating the flow direction, and two-headed arrows indicating the potential for flow reversal, including overbank flow. (Modified from Peters and Buttle, 2010).

During recent geologic time, flow pathways and areas of deposition have changed within the PAD. For instance, remnant channels that once connected the Peace River to the central delta lakes are rarely active today, and a main arm of the Athabasca River was once believed to flow through Mamawi Creek (Raup, 1935). The distributary channels of the Athabasca Delta were considered over-extended to the east in the early 1970s and migration of the active delta lobe into the central delta lakes was foreseen to take place in the near future (Bayrock and Root, 1973). To prevent the Athabasca River from eroding through its banks and joining with the Embarras River, a meander loop cut-off channel was excavated in 1972. Despite the human intervention, a natural breakthrough from the Embarras River to Mamawi Creek developed in 1982 (Fig. 1), diverting a fraction $(\sim 6 \%)$ of the Athabasca River flow and suspended sediments directly to Mamawi Lake (DeBoer et al., 1994). This diversion of Athabasca River water to the center of the PAD, not Lake Athabasca, as well as the additional surface lake areas, needs to be accounted for in present-day water balance investigations, total inflow calculations and water depths added to or drained from lake surfaces. This diversion of water was not considered in the RHD study, which along with an important oversight in lake level data used in their analyses, prompted further review of their study and drafting of this commentary.

Upon detailed review of the RHD study, a number of issues and concerns arose regarding the observed/adjusted Lake Athabasca level data used in their analyses, as well as recognition of major contemporary changes to the flow regimes influencing the level of this lake. Given the local to international focus on the study region linked to multiple upstream stressors (i.e., resource mining, hydroelectric power generation, and climate variability/change) that have and continue to influence the hydrology of Lake Athabasca and the PAD, it is important to provide details on the hydrological regime that were omitted by RHD and redo the analyses with corrected lake level data (i.e., datum reference oversight), thus providing accurate information for northerners, researchers and stakeholders involved in environmental assessments.

RHD mentioned the international importance of the PAD, yet did not highlight that the large delta lakes Claire $\left(\sim 1300 \mathrm{~km}^{2}\right)$ and Mamawi $\left(\sim 130 \mathrm{~km}^{2}\right)$ are hydraulically connected to Lake Athabasca $\left(\sim 7800 \mathrm{~km}^{2}\right)$, all of which drain into the Peace and Slave rivers via several channels. The direction of flow in the connected channels and lakes is dependent on relative water levels (dynamic relationships) between the Peace River and the lakes. Drainage is northward for most of the year, but lake outflow can be obstructed by high stage on the Peace River (variable hydraulic dam effect) and occasionally reverse when the river stage is higher than the level of the central lakes - typically during high stage events induced by spring ice river ice break-up/jams and occasional summer high flow events (Peters and Buttle, 2010). Along with inflows from the Athabasca River and surrounding rivers, flow obstruction and occasional reverse flow contribution from the Peace River was identified as a key mechanism to raising Lake Athabasca and the connected delta lakes to flood levels. Peters and Buttle (2010) reported that the occurrence of this mechanism was common during the spring break-up period prior to and following the introduction of flow regulation to the system; however, the duration of obstructed outflow from and volume of reverse flow contribution to Lake Athabasca during the open-water period had generally diminished following regulation.

RHD mention, but do not provide the reader with details, that a major alteration to the natural hydraulic outflow control on Lake Athabasca level occurred with the completion of the 
WAC Bennett Dam in the headwaters of the Peace River in late 1967. Prior to 1968 , the natural flow regime of the Peace River near the delta was characterized by low winter daily flows in the $500 \mathrm{~m}^{3} \mathrm{~s}^{-1}$ range and high summer flows peaking in the range of 7 to $11000 \mathrm{~m}^{3} \mathrm{~s}^{-1}$ (Peters and Prowse, 2001, 2006). Approximately $62 \mathrm{~km}^{3}$ of headwater runoff was stored over 1968 to 1971 to form the largest man-made lake in British Columbia and the 9th largest in the world. The low flows on the Peace River observed during the years of reservoir filling and coinciding drainage of Lake Athabasca and the connected delta lakes prompted the Peace-Athabasca Delta Project Group (PAD-PG, 1973) to investigate causes of observed low lake levels and potential mitigation measures, leading to the construction of permanent rock-fill weirs on the two of the three outflow channels in 1975/1976 (PAC-IC, 1987). Since 1972, operation of the reservoir (storage and release) to generate hydroelectricity has resulted in a $\sim 250 \%$ increase in winter and $\sim 35 \%$ reduction of summer peak daily flows to the delta (Peters and Prowse, 2001, 2006). The addition of weirs has achieved the goal of restoring average summer peak lake levels; however, the magnitude of individual extreme peak lake level events generally tend to be lower in flood years and higher in low inflow years (Peters et al., 2006). The combination of higher winter stage on the lower Peace River and hydraulic effects of the weirs have contributed to higher winter lake levels, leading to decreased annual amplitude in the Lake Athabasca level as compared to an unaltered hydrology (Prowse et al., 1996). The net result of these two major hydrologic/hydraulic alterations is a higher mean annual lake level (Aitken and Sapach, 1994; Prowse et al., 1996).

Although RHD accounted for the combined effects of flow regulation on the lake levels after 1975 in their study, they did not recognize the important alterations to the 1968-1975 Lake Athabasca levels. Figure 2a presents the 1960 to 2010 mean annual water level for Lake Athabasca near Crackingstone Point (07MC003), found in RHD. Note that for this comment paper, missing data at this site were filled in based on information from the Bustard Island (07MD002) and Fort Chipewyan (07MD001) gauging stations on Lake Athabasca. Following the contemporary historical narrative provided above clearly highlights that multiple flow and water level regimes are present in the observed hydrometric time series for Lake Athabasca and the connected delta lakes: (1) natural regime prior to 1968 , (2) initiation of flow regulation on the Peace River with filling of Williston Reservoir over 1968 to 1971 , (3) influence of hydroelectric operation on the Peace River from 1972 to 1975, and (4) combined influences of modified Peace River flows and lake outflow control structures since 1976.

A number of high and lower water cycles are evident over the $>50$ yr multi-regime lake level record presented in Fig. 2a. The short period between 1960 and the introduction of flow regulation was an era influenced by wet hydroclimatic conditions, high flows and ice jams that combined
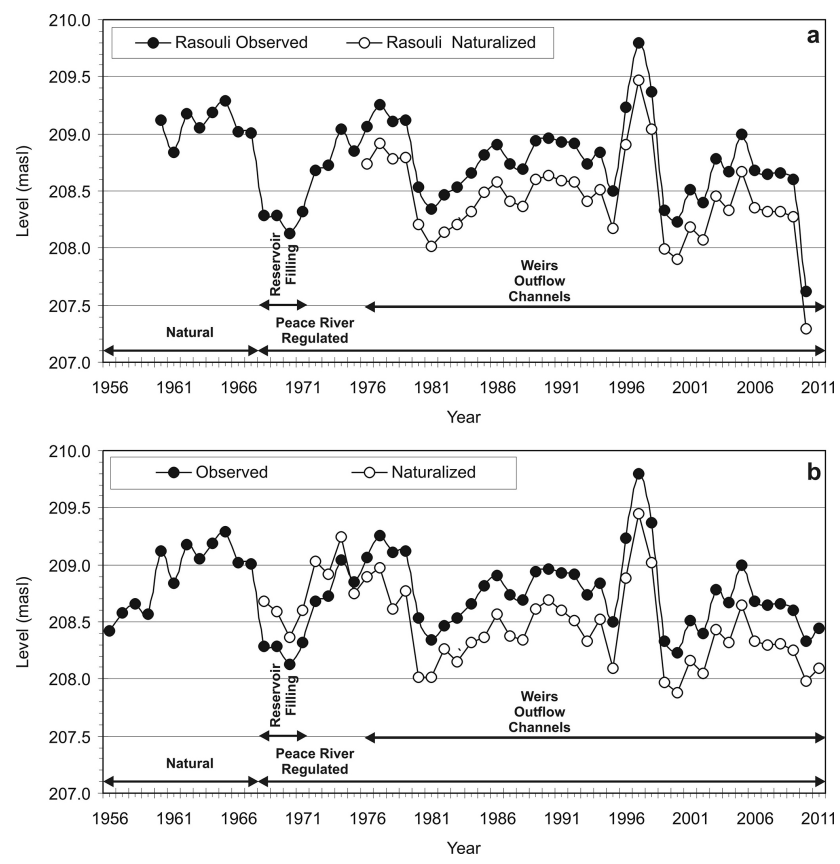

Figure 2. Observed and naturalized mean annual water level on Lake Athabasca near Crackingstone Point (a) Rasouli et al. (2013) study and (b) corrected data used for this comment paper.

to generate above-average water conditions (Peters et al., 2006; Peters and Buttle, 2010). The low water level period of 1968 to 1971 was partly influenced by diminished Peace River stage during reservoir filling, leading to enhanced Lake Athabasca and delta lake drainage. The early 1970s were characterized by a return to high water levels. For instance, 1974 was influenced by a large ice-jam flood event on the Peace and Slave rivers that blocked outflow from and diverted river water south into the PAD and Lake Athabasca system, which in combination with an ice-jam flood event on the lower Athabasca River, flooded the majority of delta wetlands (Peters et al.,2006). The early 1980s were characterized by low water level conditions, followed by mid-range conditions until the abnormally high levels in 1996 to 1998.

In addition to the occurrence of a large ice-jam flood on the lower Peace River, 1996 was influenced by a large, sustained precautionary water release from the Williston Reservoir that produced a river stage sufficiently high to restrict outflow from the lake system for several weeks over the summer months and helped, at the time, to generate the highest lake level observed since the introduction of flow regulation (Peters et al., 2006; Peters and Buttle, 2010) (Fig. 2a). The importance of this atypical event on Lake Athabasca was highlighted by Leconte et al. (2001), who estimated via hydrodynamic modeling that the peak lake level would have been $\sim 0.5 \mathrm{~m}$ lower without the enhanced reservoir release. The combination of a high lake level at the time of the freezeup, the influence of flow regulation on outflow, an ice-jam flood in the following spring, and high summer inflows, (i.e., 
highest mean annual flow on record for the Athabasca River; 07DA001; Environment Canada) led to an even higher Lake Athabasca level generated in 1997, the highest since 1960. During both summers of 1996 and 1997, Lake Athabasca and the central delta lakes expanded beyond their normal shoreline, recharging low-lying riparian wetlands (Peters et al., 2006). Subsequent drainage of the lakes in the late 1990s and early 2000s led to low lake levels near those observed during the years of reservoir filling. Other than the supposed extreme low water level observed in 2010 , the post-2002 period experienced mid-range water levels (Fig. 2a).

Examination of the station metadata (http://www.wsc. ec.gc.ca/applications/H2O/rmkNote-eng.cfm?station= 07MC003) for Lake Athabasca near Crackingstone Point hydrometric station revealed that a new geodetic datum was applied to the post-2009 data. RHD did not account for this major shift in benchmark elevation (i.e., $0.709 \mathrm{~m}$ correction to post-2009 data) in their time series analyses, thus presenting a drastic decline from 2009 to 2010 and apparently the lowest mean annual water level on Lake Athabasca since gauging began at the Crackingstone Point station in 1956 (Fig. 2a vs. b). RHD performed the Mann-Kendall trend test on pre-whitened (Yue et al., 2002 approach) time series of observed lake level data (including the uncorrected post-2009 data) and reported a $-0.008 \mathrm{~m} \mathrm{yr}^{-1}(p=0.10)$ decline in the Lake Athabasca level over 1960-2010, which they state was consistent with the significant $(p<0.05)$ decline of $-0.142 \mathrm{~km}^{3} \mathrm{yr}^{-1}$ in total input to the lake.

Based on the negative trend slope discerned for the Athabasca River annual inflow time series, as measured just below Fort McMurray (07DA001), RHD calculated an input loss of $7.38 \mathrm{~km}^{3}$ over 1960 to 2010 , translating into an equivalent lake depth decline of about $0.95 \mathrm{~m}$ based on Lake Athabasca surface area of $7800 \mathrm{~km}^{2}$. Knowing that a portion of the Athabasca River flow measured at this station ( $\sim \% \%$; DeBoer et al., 1994) was directed to Mamawi Lake after 1982 and that the central delta lakes are hydraulically connected, the depth of water reported by RDH is likely an overestimate. A more conservative estimate of the impacts of Athabasca River inflow decline on lake depth would be based on the combined Lake Athabasca, Mamawi Lake and Lake Claire surface areas, which is about $18 \%$ larger than the area used by RHD. Based on a combined area of $9230 \mathrm{~km}^{2}$ and a Sen's slope of $-0.145 \mathrm{~km}^{3} \mathrm{yr}^{-1}$ decline in flow observed at the Athabasca River just below Fort McMurray hydrometric station, a $7.38 \mathrm{~km}^{3}$ drop in inflow would translate into an equivalent $0.80 \mathrm{~m}$ water depth drop over the 1960-2010 period, yielding a closer differential to that between the first and last year $(209.118-208.330=0.79 \mathrm{~m})$ of this observed period using the geodetic-corrected data presented in Fig. 2b. The difference between these two water depth estimates may appear small at $0.15 \mathrm{~m}$, but this may be the difference between openly connected small lakes and wetlands becoming isolated from the hydraulically connected channel-lake network of the PAD. In the future, analyses of Athabasca
River inflows to the Lake Athabasca and delta lake system need to also account for the $22000 \mathrm{~km}^{2}$ of gauged/ungauged tributaries that contribute an additional $\sim 7 \%$ (deBoer et al., 1994) flow to the mainstem prior to entering the lake system, as done in Peters et al. (2013) and Monk et al. (2012).

In an attempt to extend their analyses farther back in the 20th century, RHD invoked the work of Muzik (1991) to state that the mean annual Lake Athabasca level dropped by approximately $1.64 \mathrm{~m}$ over the 1942 to 2010 period. It is unclear how RHD derived this value given that the time series analysis presented in Muzik (1991) was performed on the annual mean July water level, which typically represents the high water mark of the year, and not the mean annual lake level. Their calculation was thus likely based on the use of two different metrics, potentially leading to an exaggerated reported drop in mean annual lake level estimate since 1942. Unfortunately, we cannot redo the mean annual statistics prior to 1956 because no data exist for the Crackingstone Point station, and although there are data available at the Fort Chipewyan station back to 1931, the latter station does not reflect water level conditions for the rest of Lake Athabasca during the winter months due to ice effects (see Peter et al., 2006).

Schindler and Donahue (2006) similarly examined trends through multi-regime data (i.e., Peace River). In order to examine variability and trends influenced predominantly by climatic drivers, as is the case for the Athabasca River and surrounding inflows to the lake, it is best to remove the effects of flow regulation on the lake level to obtain naturalized water level conditions (no dam and no weir effects). Naturalization of the Lake Athabasca level was carried out by RHD in an attempt to remove the effects of flow regulation on the mean annual water level time series. Based on summary data extracted from Table 1.4.1 in PAD-TS (1996), where the mean difference between the net effect of the Bennett Dam and outflow weirs on lake levels over the 1985-1990 period was estimated via hydrodynamic modeling to be $+0.33 \mathrm{~m}$, RHD applied a static correction to the observed data for the years after 1975. RHD should have obtained the report cited in the table caption and extracted from Aitken and Sapach's (1994) naturalized mean annual lake level for the years of reservoir filling (1968-1971) and initial years of hydroelectric dam operation (1972-1975). Thus, in addition to the geodetic shift oversight highlighted above, the RHD study does not contain a complete time series of water levels for an unregulated regime because an $8 \mathrm{yr}$ period (1968-1975) of the naturalized flow regime data is not accounted for (Fig. 2a vs. b).

Several of the issues outlined above with the RHD study are addressed in this commentary paper and a revised/corrected data set is presented in Fig. 2b. Building on the previous work of Aitken and Sapach (1994), Peters et al. (2006) employed a hydrodynamic model to naturalize the flow/water levels of the lake system for the period 1968 to 1996. Note that the hydrodynamic model was calibrated for the west end of Lake Athabasca at the Fort Chipewyan station 
to investigate flow regulation and climate impacts on delta flood levels near the PAD (see Peters et al., 2006 for model calibration and validation details). An annual bias correction (mean of $-0.12 \mathrm{~m}$ ) was applied to the simulated data near Crackingstone, which were consistently higher than those observed. Following the approach of RHD, the post-1996 observed data period in Fig. 2b was adjusted by $-0.35 \mathrm{~m}$ (mean regime difference 1976-1995 in Fig. 2b) to obtain an estimate of naturalized mean annual water level. A comparison of the hydrodynamic model to the static-biased corrected data presented in this figure suggested that the naturalized data obtained via this simple approach was adequate (absolute mean difference of $0.06 \mathrm{~m}$ ) for annual time step trend analyses and the purposes of this comment paper. Future investigations should employ a hydrodynamic model to obtain more accurate values for years after 1995. It is clearly evident in Fig. 2b that in addition to climatic impacts, the filling of Williston Reservoir contributed to the low lake levels observed in the late 1960s. Without the additional influence of the outflow weirs during the years 1968 to 1971, it was estimated that the lake levels would have been higher than those observed, something not accounted for in the RHD study. As already stated above and accounted for by RHD, the addition of the two outflow weirs helped raise the mean annual lake level above those that would have occurred without the influence of regulation. This result clearly points to future projections of Lake Athabasca levels needing to include the regulated hydrologic/hydraulic conditions.

Following an approach similar to RHD, the Mann-Kendall trend detection test was applied to the pre-whitened (Yue et al., 2002) data time series (corrected for geodetic shift) presented in Fig. 2b, with a probable trend recognized at $\rho<0.10$ and a significant trend at $\rho<0.05$. Although the direction of change is consistent, the revised trend analysis results present here for the observed 1960-2010 multiregime time series period is different from RHD: significant decline of $-0.006 \mathrm{~m} \mathrm{yr}^{-1}$ vs. a probable decline of $-0.008 \mathrm{~m} \mathrm{yr}^{-1}$ (Table 1 and Fig. 2). In light of the finding of Déry et al. (2009) that the addition of years to the analysis can lead to conflicting trend results, we explored trends beyond the period examined in the RHD study. For instance, the declining trend since 1960 very slightly steepened with the addition of a 2011 data point to the observed multi-regime time series. Although remaining significant, the slope diminished considerably to $-0.004 \mathrm{~m} \mathrm{yr}^{-1}$ when the period was extended back to 1956 to include the lower water years prior to 1960 . The diminished slope is not surprising given the difference of only $0.01 \mathrm{~m}$ between the 1956 and 2011 lake levels. The most severe decline discerned for the observed time series was for the weirs- and dam-regulated period after $1975\left(-0.011 \mathrm{~m} \mathrm{yr}^{-1} ; \rho<0.05\right)$, which is the data series that reflects the current hydrological regime of the Lake Athabasca-PAD system. Interestingly, the analysis of the fully naturalized time series (no dam and weirs) with the geodetically corrected post-2009 data, yielded a result
Table 1. Comparison of Mann-Kendall trend analyses. Bold values indicate significance at 0.10 and when underlined, significance at 0.05 levels.

\begin{tabular}{|c|c|c|c|c|}
\hline \multirow[b]{2}{*}{$\begin{array}{l}\text { Lake Athabasca } \\
\text { data presented } \\
\text { in Fig. } 2 \text { b of } \\
\text { this paper }\end{array}$} & \multicolumn{4}{|c|}{ Period } \\
\hline & $1960-2010$ & $\begin{array}{r}1960-2011 \\
\beta \mathrm{m}\end{array}$ & $\begin{array}{l}1956-2011 \\
\mathrm{r}^{-1}\end{array}$ & 1976-2011 \\
\hline $\begin{array}{l}\text { Observed } \\
\text { Naturalized }\end{array}$ & $\frac{-0.006}{-0.017}$ & $\begin{array}{l}-0.007 \\
-0.017\end{array}$ & $\frac{-0.004}{-0.014}$ & $\frac{-0.011}{-0.010}$ \\
\hline
\end{tabular}

equivalent to RHD for the 1960 to 2010 period: significant decline of $-0.017 \mathrm{~m} \mathrm{yr}^{-1}$ (Table 1 and Fig. 2b). As found for the observed multi-regime hydrology, the decline was slightly lower when the lower water years prior to 1960 were included in the analysis.

The differing trend slopes discerned for the post-1956 vs. the post-1960 period is an important finding because RHD happened to start their analyses at a time of high water conditions on the lake system (Peters et al., 2006), which would influence values obtained when extrapolating a historical trend into the future. RHD extrapolated the adjusted water level data time series (Fig. 2a) to 2100 and projected a $2.4 \mathrm{~m}$ recession in the lake level by the end of this century. It is unclear why RHD report this calculation, given that the "natural" hydraulic scenario for the Lake Athabasca system no longer exists due to the influence of flow regulation on the Peace River and weirs on outflow channels. If one were tempted to extrapolate trending water levels into the near future, then the 1976-onwards flow regime (dam and weirs), which yielded a considerably less steep decline to that used by RHD, would be an appropriate scenario to base this on.

Prior to entertaining extrapolations into the future, obvious questions to answer are whether the existing hydraulic controls on lake system outflow would permit the lake to drain below those observed prior to and since 1976, and if the climatic conditions driving the observed decline will persist into the future? A scientifically defensible estimate of future lake level conditions would entail the use of hydrodynamic simulation of the current hydraulic conditions for the Lake Athabasca and PAD system with consideration of projected climate change impacts on inflows and outflow controls, including the Peace River. Pietroniro et al. (2006) assessed via hydrological/hydraulic modeling the future flow and lake level conditions for the Lake Athabasca-PAD system and concluded that although a suite of general circulation models (GCM) converged towards similar results of earlier timing of the annual peak lake level for the 2040-2069 period, the projected impacts of climate change on lake level magnitude was GCM dependent, with two models projecting higher and three projecting lower water levels. These simulated future results do not unequivocally support the severe decline projected by RHD. 


\section{Conclusions}

In conclusion, this comment paper has achieved the goal of providing key information regarding the Lake Athabasca and Peace-Athabasca Delta system, highlighting oversights in the RHD study, and presenting trend analysis results using updated lake level time series data. The inflow analysis of RHD, combined with the Lake Athabasca water level analysis presented in this comment paper, provides researchers and northerners an enhanced understanding of this system. Future assessments of Lake Athabasca and linked PAD water conditions require the application of a comprehensive water balance approach (e.g., Pietroniro et al., 2006) that takes into account the known and potential future impacts of multiple upstream and local stressors (i.e., resource mining, water abstraction, hydroelectric power generation, and climate variability/change) on ecologically relevant water level regime characteristics, such as the magnitude and timing of annual low and peak water levels.

\section{Copyright statement}

The works published in this journal are distributed under the Creative Commons Attribution 3.0 License. This license does not affect the Crown copyright work, which is re-usable under the Open Government Licence (OGL). The Creative Commons Attribution 3.0 License and the OGL are interoperable and do not conflict with, reduce or limit each other.

(C) Crown copyright 2014

Acknowledgements. Support for this study was provided by Environment Canada. I wish to thank Rajesh Strestha, Wendy Monk and Laurent deRham for their critique of an earlier draft of this comment paper.

Edited by: A. Ghadouani

\section{References}

Aitken, B., and Sapach, R.: Hydraulic modelling of PeaceAthabasca Delta under modified and natural flow conditions, Northern River Basins Study, NRBS Report No. 43, Edmonton, Alberta, Canada, 45 pp., 1994.

Bayrock, L. A. and Root, J. D.: Geology of the Peace-Athabasca Delta region, Alberta, in: Peace-Athabasca Delta Project Group, Technical Report and Appendices, Vol. 1, Hydrological Investigations, Governments of Canada, Alberta, Saskatchewan, N1N50, 1973.

DeBoer, A., Winhold, T., and Graner, L.: Embarras River breakthrough to Mamawi Creek, Peace-Athabasca Delta Technical Studies, Task D.2 - Embarras River Breakthrough, Fort Chipewyan, Alberta, Canada, 35 pp., 1994.
Déry, S. J., Hernández-Henriquez, M. A., Burford, J. E., and Wood, E. F.: Observational evidence of an intensifying hydrological cycle in northern Canada, Geophys. Res. Lett., 36, L13402, doi:10.1029/2009GL038852, 2009.

Environment Canada: HYDAT Archived Hydrometric Data, Water Survey of Canada, Downloaded from National Water Data Archive accessible at website, http://www.wsc.ec. gc.ca/applications/H2O/index-eng.cfm (last access: 28 February 2014), 2013.

Leconte, R., Pietroniro, A., Peters, D. L., and Prowse, T. D.: Effect of flow regulation and hydroclimatic conditions on the PeaceAthabasca Delta 1996 summer flood, Regul. Rivers Res. Manage., 17, 51-65, 2001.

Monk, W. A., Peters, D. L., and Baird, D. J.: Assessment of ecologically relevant hydrological variables influencing a cold-region river and its delta: the Athabasca River and the Peace-Athabasca Delta, northwestern Canada, Hydrol. Process., 26, 1828-1840, doi:10.1002/hyp.9307, 2012.

Muzik, I.: Hydrology of Lake Athabasca, Hydrology of Natural and Manmade Lakes, Proceedings of the Vienna Symposium, Vienna, Austria, August 1991, IAHS-AISH Publ., 226, 13-22, 1991.

PAD-IC: Peace-Athabasca Delta Implementation Final Report: Peace-Athabasca Delta water management works evaluation, Governments of Saskatchewan, Alberta and Canada, Edmonton, Alberta, 63 pp., 1987.

PAD-PG: Peace-Athabasca Delta Project Group Technical Report: A report on low water levels in Lake Athabasca and their effect on the Peace-Athabasca Delta, Governments of Canada, Alberta and Saskatchewan, Edmonton, Alberta, 176 pp., 1973.

PAD-TS - Peace-Athabasca Delta Technical Studies: Final Report: Peace-Athabasca Delta Technical Studies, Fort Chipewyan, Alberta, Canada, 88 pp., 1996.

Peters, D. L. and Buttle, J. M.: The effects of flow regulation and climatic variability on obstructed drainage and reverse flow contribution in a northern river-lake-delta complex, Mackenzie Basin headwaters, River Res. Appl., 26, 1065-1089, 2010.

Peters, D. L. and Prowse, T. D.: Regulation Effects on the Lower Peace River, Canada, Hydrol. Process., 15, 3181-3194, 2001.

Peters, D. L. and Prowse, T. D.: Generation of streamflow to seasonal high waters in a northern delta, northwestern Canada, Hydrol. Process., 20, 4173-4196, 2006.

Peters, D. L., Prowse, T. D., Pietroniro, A., and Leconte, R.: Flood hydrology of the Peace-Athabasca Delta, northern Canada, Hydrol. Process., 20, 4073-4096, 2006.

Peters, D. L., Atkinson, D., Monk, W. A., Tenenbaum, D. E., and Baird, D. J.: A Multi-Scale Hydroclimatic Analysis of Runoff Generation in the Athabasca River, Western Canada, Hydrol. Process., 27, 1915-1934, doi:10.1002/hyp.9699, 2013.

Pietroniro A., Toth, B., Leconte, R., Conly, M., Kouwen, N., Peters, D. L., and Prowse, T. D.: Modelling Climate Change Impacts in The Peace and Athabasca Catchment and Delta: III - integrated model assessment, Hydrol. Process., 20, 4231-4245, 2006.

Prowse, T. D., Aitken, B., Demuth, M. N., and Peterson, M.: Strategies for restoring spring flooding to a drying northern delta, Regul. Rivers Res. Manage., 12, 237-250, 1996.

Rasouli, K., Hernández-Henríquez, M. A., and Déry, S. J.: Streamflow input to Lake Athabasca, Canada, Hydrol. Earth Syst. Sci., 17, 1681-1691, doi:10.5194/hess-17-1681-2013, 2013. 
Raup, H.M.:Botanical investigations in Wood Buffalo Park, Bulletin No. 74, Biological Series No. 20, Natural Museums of Canada, Ottawa, Ontario, Canada, 174 pp., 1935.

Schindler, D. W. and Donahue, W. F.: An impending water crisis in Canada's western prairie provinces, P. Natl. Acad. Sci., 103, 7210-7216, 2006.
Wolfe, B. B., Edwards, T. W. D., Hall, R. I., and Johnston, J. W.: A 5200-year record of freshwater availability for regions in western North America fed by high-elevation runoff, Geophys. Res. Lett., 38, L11404, doi:10.1029/2011GL047599, 2011.

Yue, S., Pilon, P., Phinney, B., and Cavadias, G.: The influence of autocorrelation on the ability to detect trend in hydrological series, Hydrol. Process., 16, 1807-1829, 2002. 